\author{
Iwona Boruszkowska iD https://orcid.org/0000-0001-8021-9210 \\ Wydział Polonistyki UJ \\ iwona.boruszkowska@uj.edu.pl
}

\title{
La mortelega grande, czyli „wiellkie umieranie”. Zaraza jako katastrofa (w) wyobraźni
}

\author{
La Mortelega Grande or the "Great Mortality:" Pestilence as a Disaster for/in \\ the Imagination
}

\begin{abstract}
The present paper discusses two examples of literary depictions of epidemics: the libretto Zaraza w Bergamo (1897) by Young Poland writer and critic Karol Irzykowski and the novel Palę Paryż (1928) by Polish futurist author Bruno Jasieński, with both works exemplifying the trend to use the metaphor of pestilence to create a pessimistic image of reality. The author points out that interest in disease and epidemic as a literary subject often grows in the times of radical change and crises. The narratives of pestilence, plague or other collective threat in modernist and interwar literature were examples of apocalyptic narratives. The output of Polish modernist and avant-garde writers encompassed the entire spectrum of catastrophic themes, even if the range of disasters was limited only to plagues: the Black Death, cities ravaged by the bubonic plague, and raging epidemics of deathly flu strains frequently featured on the pages of literary works produced in the $19^{\text {th }}$ and the $20^{\text {th }}$ century.
\end{abstract}

Keywords: Karol Irzykowski, Bruno Jasieński, epidemic, pestilence, disaster

Streszczenie: Artykuł omawia dwa literackie przykłady reprezentacji epidemii: libretto młodopolskiego pisarza i krytyka Karola Irzykowskiego Zaraza w Bergamo (1897) oraz utwór przedstawiciela polskiego futuryzmu - Brunona Jasieńskiego Palę Paryż (1928), które ukazują tendencje do pesymistycznego ujmowania rzeczywistości poprzez metaforę zarazy. Autorka wskazuje, iż zainteresowanie twórców chorobą i epidemią jako tematem literackim powraca w momentach przełomów i kryzysów. Narracje o zarazie, pladze czy innym powszechnym zagrożeniu będą w literaturze modernistycznej i międzywojennej reprezentowały właśnie narracje katastroficzne. Twórczość polskich modernistów i awangardzistów ujmuje bowiem całe spektrum katastroficznych tematów, nawet jeśli katastrofę zawęzić do plagi: morowa zaraza, zadżumione miasta i szalejące śmiertelne grypy goszczą na kartach literatury XIX i XX wieku.

Słowa kluczowe: Karol Irzykowski, Bruno Jasieński, epidemia, zaraza, katastrofa 
Wśród tematów, dla których nowa sztuka próbowała wynaleźć nowy język, znajdują się także wielokrotnie wyzyskiwane i reinterpretowane takie motywy, jak choroba, epidemia, kryzys, kres. Twórczość polskich modernistów i awangardzistów szeroko prezentuje bowiem całe spektrum katastroficznych tematów, nawet jeśli katastrofę zawęzić do plagi, to morowa zaraza, zadżumione miasta, przywleczona z Azji cholera, bakcyle i szalejące śmiertelne grypy goszczą na kartach literatury XIX i XX wieku.

Rene Girard wskazywał, iż okresy epidemii są czasem kryzysu społecznego $^{1}$. Zaś na graniczny - za Karlem Jaspersem - charakter doświadczenia epidemii czy zarazy zwracała uwagę Monika Sznajderman, pisząc: „Jako stały element mitologicznego scenariusza towarzyszy wszelkim kryzysom, katastrofom i przełomom dziejowym. Jest znakiem końca świata"2. Pytania o chorobę i zainteresowanie twórców epidemią jako tematem literackim powracają w momentach przełomów i kryzysów. Narracje o epidemii, chorobie, zarazie, pladze czy innym powszechnym zagrożeniu będą w literaturze modernistycznej i międzywojennej reprezentowały właśnie narracje katastroficzne. Tendencje do pesymistycznego ujmowania rzeczywistości poprzez metaforę zarazy odnajdziemy w libretcie krytyka awangardy Karola Irzykowskiego (Zaraza w Bergamo, 1897), w utworach przedstawiciela polskiego futuryzmu - Brunona Jasieńskiego (Pale Paryż) czy w powieści obrazującej kryzys lat trzydziestych (Grypa szaleje w Naprawie) Jalu Kurka. O przypadającym na lata 1918-1932 wzmożeniu produkcji literackiej w obrębie dyskursu katastroficznego i pojawieniu się typu powieści popularnej, zwanej przez Ignacego Fika „powieścią katastrofową", pisze Krystyna Kłosińska, iż sytuacja społeczno-polityczna pozwala uzyskać utworom „mocniejszy kontekst katastroficzny”3.

Teksty metaforyzujące epidemię wpisują się w tradycję narracji katastroficznych czy wręcz apokaliptycznych, co wyraźnie widać w okresach kultury naznaczonych kryzysem. Wśród dotychczasowych prób definiowania katastrofizmu literackiego pojawiają się różnorodne propozycje. Dla Kazimierza Wyki jest on zjawiskiem, które polegało na „podawaniu tematów, jakie sugerowały i zapowiadały nieuchronną katastrofę (...) zagrażającą ówczesnemu światu, tematów o osnowie przeważnie filozoficznej, a także społeczno-politycznej”‘ . W polu tak rozumianego katastrofizmu mieściłyby się literackie reprezentacje zarazy.

Powstające na przełomie XIX i XX wieku (bądź w pierwszych dziesięcioleciach wieku XX) utwory, w których plaga stanowi nadrzędny motyw, pojawiają się w nurcie katastrofizmu, dość szeroko ujmowanego jako zjawisko

1 R.R. Girard, Koziot ofiarny, tłum. M. Goszczyńska, Łódź 1987.

2 M. Sznajderman, Zaraza. Mitologia dżumy, cholery i AIDS, Warszawa 1994, s. 5.

3 K. Kłosińska, Katastroficzna odmiana powieści popularnej [w:] Katastrofizm i awangarda, red. T. Bujnicki, T. Kłak, Katowice 1979, s. 58.

4 K. Wyka, Wspomnienie o katastrofizmie [w:] tegoż, Rzecz wyobraźni, Warszawa 1977, s. 291. 
ideowo-artystyczne ${ }^{5}$ czy tendencja w kulturze XIX i XX wieku. Analogicznie wygląda sytuacja literatury nam bliższej, bowiem współczesne (pierwsze dziesięciolecie XXI wieku) utwory o epidemiii ${ }^{6}$ to teksty postapokaliptyczne, w których ostateczną katastrofą jest właśnie globalna choroba. Narracje zarazy obrazują kataklizm, ludzką egzystencję w sytuacji granicznej czy skutki epidemii w postaci powszechnego lęku przed chorobą ukazaną w retoryce katastroficznej.

\section{Tragifarsa (z) zarazy}

Zaraza - ze swoją długą tradycją literackich reprezentacji - pojawia się także w młodopolskim horyzoncie oczekiwań czytelniczych i zainteresowań pisarskich. Nie dziwi to w żadnej mierze, ponieważ zagadnienia powszechnej choroby, pandemii czy innych sytuacji granicznych wpisują się w schyłkowy klimat epoki, przeczucie kresu oraz świadomość kryzysów, jakie ciążą na podmiocie modernistycznym. Karol Irzykowski podejmuje się zobrazowania (raczej symboliczno-egzemplifikacyjnego) bliżej nieokreślonej pandemii w dramacie $Z a$ raza w Bergamo (1897), który uważa się za realizację poetyki modernizmu. W utworze dominują bowiem „ujęcia groteskowe, (...) niedokończenia, fragmentaryczność, otwarcia (...) oraz dążenie do stworzenia własnego, niepowtarzalnego stylu"'. Chorobę, jak wszelką inność, ukazuje młodopolski twórca za pomoca „łącznia ze sobą elementów innorodnych, oksymoronicznych, swoistą niezbornością"8. Najprawdopodobniej świadomie obrana dla przedstawienia zarazy literacka kategoria „dziwności” czy „niezwykłości” opiera się na elementach alegoryzacji - brak konkretyzacji czasu czy momentu historycznego, brak uściśleń w materii choroby, nie wiemy, z jaką zarazą borykają się mieszkańcy Bergamo. Wybór miejsca, choć bez historycznej konkretyzacji, nie wydaje się w Zarazie... przypadkowy. Irzykowski świadom tego, że Bergamo kilka razy dotykały różne epidemie, między innymi średniowieczne epidemie dżumy czy epidemia cholery w 1886 roku$^{9}$, uczynił z miasta symbol miejsca dotkniętego morem. Rezultat osiągnięty przez autora dzięki tym zabiegom zbliża utwór do dramatu symbolicznego, do formy pewnej uniwersalnej przypowie-

5 Jerzy Speina określa katastrofizm jako „pewną postawę ideową i światopoglądową”, zob. J. Speina, Powieści Stanisawa Ignacego Witkiewicza, Toruń 1965, s. 15.

6 Dla przykładu narracje postakopaliptyczne w obrębie literatury popularnej: Infekcja Andrzeja Wardziaka czy Szczury Wroctawia Roberta Szmidta.

J. Waligóra, Mtodopolska discors concordia. "Zaraza w Bergamo” Karola Irzykowskiego [w:] Cztowiek wobec epidemii chorób zakaźnych od starożytności po czasy wspótczesne w świecie literatury i medycyny, red. E. Łoch, G. Wallner, E. Fllis-Czerniak, t. 9, Lublin 2011, s. 85.

8 Tamże.

9 Zob. F.F. Cartwright, M. Biddiss, Niewidoczny wróg. Zarazy i historia, tłum. M. Wyrwas-Wiśniewska, Warszawa 2005, s. 126-146. 
ści o winie i karze, gdzie karą jest epidemia („Bóg zesłał czasy prób!”10), której towarzyszą złowieszcze oznaki („W powietrzu dziwna woń,/ We wodzie dziwny jad"11). Sprawdza się tu teza, którą John Aberth zawarł w Spektaklach masowej śmierci, iż „Idea plagi (...), stanowiła powszechną spuściznę po starożytnych: wszyscy oni postrzegali chorobę jako karę lub próbę, której poddawani byli ludzie"12. Przedstawianie epidemii jako boskiej zemsty na nieposłusznych ludziach nie jest jedynym jej wytłumaczeniem, choć było często stosowaną interpretacją choroby od czasów najdawniejszych.

W kontekście literackim Zarazy w Bergamo Irzykowskiego znajdują się pokrewne tematycznie libretta Uczty podczas dżumy Aleksandra Puszkina (1900) do oper Cezara Cui (1900) i Sergiusza Prokofjewa (1903) ${ }^{13}$. Całość otwiera zawierający elementy sakralne obraz epidemii jako boskiej kary: anioł śmierci pląsający w powietrzu i strząsający zarazę ze swoich skrzydeł (s. 133) oraz wychodzący z kościoła wierni rozpaczliwie wołający o miłosierdzie i pomoc. Nie znajdziemy u Irzykowskiego niemal żadnych konkretów w sposobie prezentowania zarazy, jedynie symboliczne, przerysowane, groteskowe czy uniwersalizujące obrazy. Jednak wspólny Zarazie w Bergamo i innym literackim reprezentacjom zarazy będzie powszechny lęk przed zarażeniem, nieufność i podejrzliwość względem innych, unikanie osób potencjalnie zarażonych i dystansowanie społeczne („Dlaczego mnie unikasz”, „Dlaczego cofasz krok”" ${ }^{14}$, „Ach, precz!”15). Ów lęk przed zarazą jako czymś odwiecznym ${ }^{16}$, a obawa o własne życie prowadzi do ambiwalencji postaw i zachowań oraz wykluczających działań mieszkańców miasta względem siebie, na przykład w stosunku do kobiety, której kochanek zmarł („Zamykaj się co tchu,/ Zarazy nie szerz tu!”) ${ }^{17}$ - chcą zamurować jej drzwi i zamknąć w domu z trupem, skazując na zarażenie i pewną śmierć („W tym domu leży trup,/ Więc niech to będzie grób”18). Innym sposobem poradzenia sobie z zarazą jest wydany przez włodarzy miasta nakaz podpalenia, tak by pożar strawił „moru zgniłe łono” (s. 133), a wówczas „świeże znów powietrze nam zaszumi” (s. 133). Apokaliptyczny obraz płonącego „miasta cmentarzy" (s. 137) wzmocniony zostaje porównaniem do rozwartego piekła, gdzie „Wśród płomienistej otchłani/ Morowa tańczy pani” (s. 137). Makabryczny

10 K. Irzykowski, Zaraza w Bergamo [w:] tegoż, Wiersze i dramaty, red. A. Lam, Kraków 1977, s. 129.

11 Tamże.

12 J. Aberth, Spektakle masowej śmierci. Plagi, zarazy, epidemie, tłum. L. Karnas, Warszawa 2012, s. 20.

13 A. Wiedemann, Konceptualizm literacki Karola Irzykowskiego: dziennik, wiersze, dramaty, „Pamiętnik Literacki” 1995, nr 4, s. 24.

14 K. Irzykowski, dz. cyt., s. 129.

15 Tamże, s. 130.

16 J. Ruffié, J.Ch. Sournia, Apokalipsa dżumy [w:] tychże, Historia epidemii. Od dżumy do AIDS, tłum. B.A. Matusiak, Warszawa 1996, s. 76.

17 K. Irzykowski, dz. cyt., s. 131.

18 Tamże, s. 132. 
obraz dopełniają drapieżne ptaki, które unoszą się nad miastem, a w swoich szponach mają „,iał ludzkich strzępy” (s. 134). Przestrzeń miasta w tej „epidemicznej farsie" zamieszkana jest przez różne indywidua.

Całość utworu stanowią luźno powiązane ze sobą sceny, wycinki epidemicznej rzeczywistości, a treść wypełniają różnorodne postawy bergamczyków wobec zagrożenia pomorem: oszalały z lęku przed chorobą Starzec opisujący płonące Bergamo postrzegany jak szaleniec, Ksiądz kapitulujący w obliczu nieszczęścia, filozof z obciętymi uszami, Ricardi rodem z piekła. Nawet w tych luźnych impresjach na temat zarazy, gdzie z jednej strony pojawiają się groteskowe obrazy orgii w płonącym mieście, z drugiej - portrety ascetów i biczowników, próbujących odpokutować grzeszne czyny, można się doszukać symbolicznych przedstawień zarazy i reprezentacji postaw jednostek w sytuacji granicznej oraz tłumu w sytuacji zagrożenia.

Ze względu na symbolikę wykorzystaną przez Irzykowskiego pierwszym skojarzeniem jest umieszczenie dramatu w kontekście apokaliptycznym: wszak Zaraza to jeden z jeźdźców Apokalipsy: „Już według przepowiedni Apokalipsy mór był jedną z klęsk, jakie miały dosięgnąć grzeszników, uważano go więc za boską karę i usiłowano znaleźć winnych" ${ }^{19}$. Pomór w Bergamo można interpretować w tym właśnie szerszym kontekście niechybnej śmierci, zagłady czy wreszcie apokalipsy - kresu i ostatecznego końca. W tej sytuacji polaryzują się dwie postawy: wpatrzona $\mathrm{z}$ nadzieją w stronę sacrum postawa ascetów i pozostająca po stronie profanum postawa tych, co „cnotę zawieszają na kołku” (s. 144) i uczestniczą w biesiadzie samozwańczego filozofa, który uważa, że nie sposób uciec przed zarazą, i nawołuje do orgii (gra w kości o kobietę, bójki na noże, cudzołóstwo, parodie mszy, kamieniowanie zarażonego). Temu wielogłosowi postaw towarzyszy podział w obrębie budowy wybranej przez Irzykowskiego formy dramatycznej: partie postaci i chóru (Tłum, Chór Biczowników), zróżnicowane głosy poszczególnych bohaterów. Zestawiono tu dwie postawy wobec zarazy: pierwiastek apolliński i dionizyjski, boski i szatański, kapłan/lekarz i zdegenerowany filozof zarazy. Występujące tu postaci to niemal figury alegoryczne czy też archetypy reprezentujące myślenie kolektywne w sytuacji kryzysu czy katastrofy, dla których - jak twierdzi Sznajderman - ,szeroko pojęte doświadczenie sacrum w kulturze - to naturalne środowisko fenomenu zarazy" ${ }^{20}$.

Starzec i Ricardi obierają wyraźną postawę wobec śmiertelnego zagrożenia. Pierwszy poszukuje drogi zrozumienia tego, co się wydarza, jednak stoicki spokój i nadzieja szybko go opuszczają, gdy wokół coraz więcej śmierci, nie może już czerpać radości z rozkoszy cielesnych i ostatecznie wybiera ascezę. Drugi przepełniony wątpliwościami co do racjonalnych i intelektualnych możliwości walki ze śmiercią kończy swoje życie w groteskowej biesiadzie. Badacze historii epidemii wskazują, że „powszechne rozluźnienie norm moralnych oraz

19 J. Ruffié, J. Ch. Sournia, dz. cyt., s. 94.

20 M. Sznajderman, dz. cyt., s. 6. 
cyniczny i smutny pościg za uciechami życia” ${ }^{21}$ były naturalną reakcją na egzystencję zagrożoną śmiertelną chorobą. Inną reakcją była „masochistyczna postawa przyjęcia na siebie boskiej kary" ${ }^{22}$, objawiająca się w masowym samobiczowaniu. W utworze pojawia się Asceta, który realizuje to inne podejście i nawołuje do skruchy, przebłagania Boga za grzechy, za które karą jest zaraza:

Czarna śmierć była boską karą, zatem biczowanie stanowiło próbę jej odwrócenia przez dobrowolne nałożenie na siebie innej kary. Stąd pojawienie się biczowników wiązało się raczej z pogłoskami o zarazie niż z samym jej wybuchem. Próbowano po prostu odwrócić karę od innych ludzi, wymierzając ją sobie samodzielnie ${ }^{23}$.

Bohaterowie Irzykowskiego, niezależnie od postawy względem epidemii, uznają bezcelowość ludzkiej egzystencji i kruchość istnienia, są zagubieni i pozbawieni pewności, nie wiedzą, w jaki sposób mierzyć się z katastrofą w postaci plagi, światem w rozpadzie, irracjonalnością zarazy. Mór nie tylko przypomina o kruchości istnienia, ale także ukazuje, że „struktury społeczne, mające (...) chronić obywateli w trudnych warunkach, były równie niepewnie i nieustannie zagrożone" ${ }^{24}$.

\section{Zbuntowany bakcyl rewolucji - Palę Paryż Brunona Jasieńskiego}

Temat epidemii podjął również awangardowy pisarz Jasieński, w którego twórczości dochodzą do głosu lewicowe przekonania, czyni on bohaterami swoich utworów robotników, przedstawia burżuazyjny wyzysk i niedole proletariatu. Próbuje w mocno utopijnych (czy wręcz dystopijnych) wizjach nakreślić nowy światowy ład, który nastanie po rewolucji proletariackiej. W Palę Paryż Jasieński obmyśla świat wymagający radykalnej przebudowy, a nowy ład można wprowadzić, jedynie zrównując zastaną rzeczywistość z ziemią - w tym wypadku za pomocą wpuszczonego do wodociągów metropolii wirusa.

Jasieński przebywał w stolicy Francji od 1925 do 1929, kiedy to z powodu publikacji kontrowersyjnej powieści Palę Paryż, w której metropolia zostaje skazana na zniszczenie, zostaje wydalony z kraju ${ }^{25}$. Przez te kilka lat ma okazję przyjrzeć się życiu miasta: odmalował je w drukowanych w „Wieku Nowym”

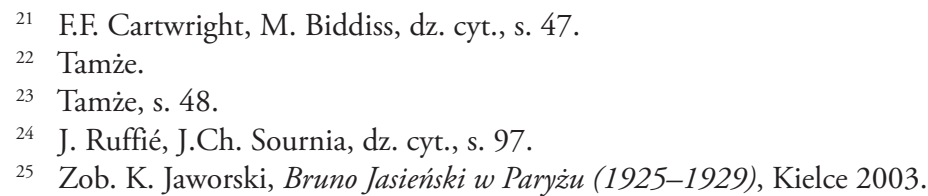


listach ${ }^{26}$, a w powieści Palę Paryż stworzył literacki portret miasta czasów zarazy. Już w wyborze tytułu utworu badacze dopatrują się politycznego gestu Palę Paryż miał być bowiem odpowiedzią na antyradziecką nowelę Paula Moranda Pale Moskwę $e^{27}$.

Powieść Jasieńskiego osadzić można w nurcie katastrofizmu charakterystycznym dla czasów, w których powstawała. Awangardowy pesymizm, wynikający z przeżytych i przeczuwanych traum ${ }^{28}$ pierwszych dziesięcioleci XX wieku, zawładnął wyobraźnią także innych autorów, wśród których wskazać można Witkacego z jego powieściami (choćby Nienasycenie czy Pożegnanie jesieni), Romana Jaworskiego i jego Wesele hrabiego Orgaza (1925), Aleksandra Wata z cyklem Bezrobotny Lucyfer, Kurka i jego powieści S.O.S. (Zbaw nasze dusze) czy Kim byt Andrzej Panik albo choćby Anatola Sterna z poematem Europa. Mimo deklarowanego przez futurystów optymizmu cywilizacyjnego czołowy polski przedstawiciel tego nurtu nie unikał gatunku powieści katastroficznej, czy wręcz apokaliptycznej (to określenie Jerzego Szymańskiego, „powieścią społeczno-fantastyczną" nazywa ją Stern ${ }^{29}$, a inni - jak na przykład Tadeusz Bujnicki - antykapitalistyczną ${ }^{30}$ ). Jednak schyłkowe nastroje ukazane w Pale Paryż związane są ściśle z sytuacją społeczno-polityczną, nie zaś z przeczuwanym końcem świata czy powszechnie panującym kryzysem. Pisząc o polskiej literaturze proletariackiej, Józef Łobodowski ujął powieść Jasieńskiego jako „nie tylko frapującą lekturę agitacyjną, ale również jedną z najlepszych polskich powieści" ${ }^{31}$. Utwór komentowano jako powieść, będącą głosem w politycznej debacie o literaturze proletariackiej czy społecznej, twórczości zaangażowanej, podporządkowanej ideologii. Późniejsi krytycy wskazywali na utopijność myśli Jasieńskiego i niebezpieczeństwa płynące ze strategii artystycznej podporządkowanej przebudowie świata według haseł socjalizmu ${ }^{32}$.

Powieść Jasieńskiego w przeciwieństwie do wymienionych wyżej utworów prezentujących katastrofę w stylu buffo, nie zdradza pociągu do groteski,

26 O cyklu Jasieńskiego Listy z Paryża zob. J. Dziarnowska, Stowo o Brunonie Jasieńskim, Warszawa 1978, s. 125-138.

27 P. Morand, Pale Moskwę [w:] tegoż, Swawolna Europa, Warszawa 1928. Zob. polemiki na temat inspiracji powieścią Moranda i genezy tytułu Palę Paryż zebrał i opisał we wstępie do jednego z wydań powieści P. Kitrasiewicz, Morand-Jasieński. Pojedynek na miasta [w:] B. Jasieński, Palę Paryż, Warszawa 2005.

28 Wzmacnianych przez literacką, artystyczną czy filozoficzną refleksję na temat końca, kresu, zmierzchu (Zmierzch Zachodu Oswalda Spenglera, Upadek cywilizacji Zachodniej Floriana Znanieckiego czy inne), charakterystyczną dla modernistycznego dekadentyzmu.

29 A. Stern, Bruno Jasieński, dz. cyt., s. 141.

30 T. Bujnicki, Bruno Jasieński [w:] Literatura polska w okresie międzywojennym, red. I. Maciejewska, J. Trznadel, M. Pokrasenowa, t. 3: Obraz literatury polskiej XIX i XX wieku, Kraków 1993, s. 165-208.

31 J. Łobodowski, Literatura proletariacka, „Kurier Lubelski”, 26.03.1932, nr 86.

32 Zob. między innymi P. Mitzner, Śmierć futurysty, „Karta” 1993, nr 11, czy publikacje Krzysztofa Jaworskiego o Jasieńskim. 
parodii czy drwiny ${ }^{33}$, tworząc obraz raczej utopijny. Wspólne dla zespołu katastroficznych motywów są w powieści „nieuchronność zagłady i związane z nią symptomy dezintegracji społecznej, wynaturzenie kultury i cywilizacji, rewolta zbuntowanej masy" ${ }^{34}$. Na tych planach zakwestionował Jasieński zarówno status francuskiej metropolii jako centrum świata kultury, jak i kapitalizmu jako najlepszego ekonomicznego systemu, a także ukazał dezintegrację demokracji, rodzącej jedynie podziały i konflikty społeczne, a mieszczańską formację kulturową - jako archaiczną. W idealizującej system socjalistycznej organizacji społeczno-politycznej wizji autor dokonał zagłady jedynie wybranych elementów rzeczywistości, na gruzach których powstaje nowy komunistyczny ład, a całość zakończył wezwaniem do powszechnej światowej komunistycznej rewolucji.

W recenzji Andrzeja Stawara z 1929 roku (rok ukazania się powieści w wydawnictwie „Rój”) pada sformułowanie: „Zamierzona była ponoć powieść rewolucyjna, wyszła zaś z warsztatu literackiego powieść apokaliptyczna"35. I rzeczywiście programowy radykalizm w warstwie języka nie zbliża się do wzorców literatury socjalistycznej, mimo obrania w trzecim rozdziale konwencji prozy reportażowej eksfuturysta naraził się na krytykę pisarzy lewicowych i nie tylko ${ }^{36}$.

Jak słusznie zauważa jeden z interpretatorów twórczości prozatorskiej Jasieńskiego, Bujnicki, trzy części powieści Palę Paryż utrzymane są w różnych konwencjach: powieści brukowej, symultanicznych nowel, prozy reportażowej ${ }^{37}$, różni je tematyka poruszana w trzech częściach i wybrane przez autora rozwiązania formalne. Niezależnie jednak od obranej konwencji powieść jest topograficznie realistyczna i stanowić mogłaby swoisty bedeker Paryża lat dwudziestych (na kartach powieści padają nazwy ulic, budowli, świątyń, kawiarni, zaułków, charakterystycznych punktów, takich jak Pola Elizejskie czy Łuk Triumfalny, a nawet całych dzielnic). Na pytanie, dlaczego autor tak szczegółowo odmalowuje literacki portret Paryża, odpowiada badacz twórczości Jasieńskiego:

Dla miasta, które ma być zniszczone, prawdopodobieństwo topograficzne musiało być posunięte do maksimum. (...) Szczegół miał tu za zadanie potęgować zagrożenie tak, by przemierzając Paryż, niemal czuć wiszącą w powietrzu apokalipsę,

33 Zob. M. Rawiński, Wobec mitu zagrożenia Zachodu (O „Palę Paryż” Brunona Jasieńskiego) [w:] O prozie polskiej XX wieku, red. A. Hutnikiewicz, H. Zaworska, Wrocław 1971.

34 T. Bujnicki, Bruno Jasieński..., dz. cyt., s. 177.

35 J. Szymański [A. Stawar], „Palę Paryż”, „Miesięcznik Literacki” 1929, nr 1.

36 Z powodu istnienia różnych wydań i wersji powieści Palę Paryż sprawia niemały kłopot interpretatorom: zastanawiać się można, która z wersji powieści stanowi ostateczną (jeżeli takie stanowisko w ogóle można uzgodnić)? W Rosji ukazały się wersje powieści z zupełnie innym zakończeniem, jak podkreśla Edward Balcerzan - były to wersje dopasowane do wymogów realizmu socjalistycznego: E. Balcerzan, Styl i poetyka twórczości dwujęzycznej Brunona Jasieńskiego, Wrocław-Warszawa-Kraków 1968, s. 326, 321-328; zob. też: N.N. Kolesnikoff, Bruno Jasieński: His Evolution from Futurism to Socialist Realism, Waterloo, Ont. 1982.

37 T. Bujnicki, Twórczość prozatorska Brunona Jasieńskiego [w:] tegoż, Bunt żywiotów i logika dziejów. W kregu idei polskiej lewicy, Katowice 1984, s. 180-185. 
tragedię, która rozegra się tu i teraz, na oczach współczesnych, w konkretnym miejscu i czasie ${ }^{38}$.

Fabuła powieści nie wydaje się nader skomplikowana - w pierwszej części biedny robotnik Pierre traci pracę, przychylność dziewczyny Jeannette i dach nad głową, a wydaje się też, że z powodu nękającego go głodu - również i zmysły. Upokorzenie, wyczerpanie i głód powodują osuwanie się bohatera w stan delirium, doprowadzają go na skraj psychicznej i fizycznej wytrzymałości, powodują szaleństwo, egzystencję na granicy jawy i snu - „poza granicą trójwymiarowej rzeczywistości” ${ }^{39}$, a przynajmniej zaburzenia i deformacje rzeczywistości: „świat załamujący się w obłąkanej wyobraźni bohatera jest (...) odbiciem zdeformowanej struktury kapitalistycznej rzeczywistości i jej absurdu”²0. Burżuazyjna, kapitalistyczna metropolia jawi się biednemu robotnikowi jako potwór, opozycja burżuazyjnego przesytu i socjalistycznego niedosytu prowadzić może jedynie do upadku, do zniszczenia, do rewolucji. Nie jest to oczywiście jedyne możliwe odczytanie - odrealnienia opisu i zniekształcenia rzeczywistości można uznać za surrealne eksperymenty prozatorskie.

Główny bohater pierwszego rozdziału błąka się paryskimi ulicami, trafia do więzienia, aż w kluczowym punkcie ratuje go kolega z lat młodości - Rene, zabiera bezdomnego do siebie. Los się odwrócił: Pierre dostaje pracę w „wie-

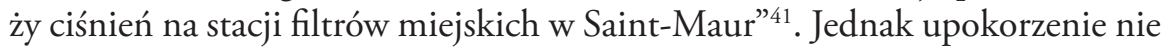
mija i bohater postanawia w akcie zemsty zatruć Paryż zarazkami dżumy hodowanej w laboratorium, w którym pracuje jego przyjaciel i wysłać zarazę w „wygłodniałe arterie dalekiego, śpiącego Paryża” ${ }^{42}$.

Pozostałe wątki części drugiej są luźno powiązane, niejako odseparowane od siebie niemal jak niezależne państewka utworzone na terenie Paryża w trakcie epidemii dżumy, do której doprowadził desperacki gest Pierre'a. W centralnym rozdziale powieści splatają się wątki skupione wokół postaci: chińskiego komunisty P'ana Tsiang-Kueia (wcielenie dojrzałego ideologicznie rewolucjonisty), rabina gminy żydowskiej Eleazara ben Cwiego (stereotyp przedstawiciela narodu wybranego), Rosjanina białogwardzistę rotmistrza Sołomina (uosobienie okrucieństwa i anachronizmu politycznej emigracji), amerykańskiego miliardera Dawida Lingslaya (symbol kapitału rządzącego światem), towarzysza komunistę, kapitana Czerwonej Gwardii Jacquesa Lavala (ideał romantycznego rewolucjonisty ginącego za swoje przekonania). Każdy z nich w jakiś sposób trafia do Paryża i podczas epidemii pełni funkcję przywódcy jednego

38 K. Jaworski, Przestrzeń fabularna i uksztattowanie języka narracji a idea polityczna. Na przyktadzie powieści Brunona Jasieńskiego „Palę Paryż”, „Studia Filologiczne Akademii Świętokrzyskiej" 2002, t. 17, s. 103.

39 B. Jasieński, dz. cyt., s. 34.

40 T. Bujnicki, Twórczość prozatorska..., dz. cyt., s. 182.

41 B. Jasieński, dz. cyt., s. 45.

42 Tamże, s. 52. 
z separatystycznych państewek, które powstają na terenie miasta. Zbiorowiska konstytuują się w niezależne parapaństwowe organizmy przedzielone kordonami i różnorodne pod względem ustroju, narodowości czy religii: republika „żółtych”, żydowska gmina, anglo-amerykański „trust” najbogatszych, republika radziecka, rosyjska monarchia, odrestaurowana monarchia Burbonów i zorganizowane w części trzeciej państwo więźniów proletariackich. Na czele pierwszej z nich staje P'an, który działa w szeregach partii komunistycznej w Nankinie i jako tajny jej agent zostaje oddelegowany do Europy, aby szerzyć rewolucję chińską. Narrator poświęca mu zdecydowanie najwięcej uwagi, szczegółowo rekonstruując jego dzieciństwo i dojrzewanie ideologiczne. Jest uświadomionym politycznie i ideowo wyznawcą marksizmu i zdecydowanie najszerzej prezentuje swoje poglądy na temat rewolucji chińskiej i ruchów antykolonialnych w Azji. W rozmowie z profesorem Sorbony deklaruje:

Wasza nauka, z której jesteście tacy dumni i którą przyjeżdżamy do was studiować, nie jest systemem narzędzi panowania człowieka nad przyrodą, lecz systemem narzędzi panowania Europy nad nie-Europą, systemem narzędzi wyzysku słabych kontynentów. (...) To my, sadzący ryż, hodujący bawełnę i herbatę, jesteśmy na równi z waszym własnym proletariatem właściwymi, chociaż pośrednimi twórcami waszej kultury ${ }^{43}$.

Z każdą z naszkicowanych mniej lub bardziej schematycznie czy stereotypowo postaci i z każdym z powstałych na terenie zadżumionego Paryża państewek wiąże się funkcjonujący w latach dwudziestych XX wieku w Europie mit, z którym Jasieńskie zdaje się rozprawiać: mit o „żółtym niebezpieczeństwie" wielkiej chińskiej armii idącej na Europę, mit o syjonistycznym spisku, mit o wszechpotędze bajecznego amerykańskiego kapitału, o widmie komunizmu krążącego nad Europą i czerwonym niebezpieczeństwie bolszewizmu ${ }^{44}$. Co ciekawe, w schematach popularnej powieści katastroficznej wskazywanych przez Kłosińską, mit o zagrożeniu z Azji jest częstym elementem fabuły. Badaczka twierdzi, iż wspomniany inwariant międzywojennej powieści katastroficznej „podnosi mity i stereotypy zrodzone zarówno przez doświadczenia historyczne pierwszej wojny światowej i rewolucji w Rosji, jak i powiela, a raczej schematyzuje, przystosowując do własnych celów publicystyczne, filozoficzne i literackie wersje katastrofizmu" ${ }^{45}$. W powieści o zarazie w metropolii Jasieński sięga do antycywilizacyjnych mitów, między innymi tych o zagrożeniu ze Wschodu - czy w postaci „bolszewickiej dziczy” czy „żółtego/czerwonego niebezpieczeństwa”. Dżuma staje się katalizatorem obaw, Paryż (symbol Zachodu) ginie pod naporem katastroficznych lęków niszczących ówczesną świadomość.

\footnotetext{
43 Tamże, s. 119.

44 Zob. M. Rawiński, dz. cyt.

45 K. Kłosińska, dz. cyt., s. 71.
} 
Bohater nowej idei postępu - robotnik Pierre, nie wciela się w rolę budowniczego, lecz staje się niszczycielem. Jego projekt jest projektem obliczonym na odwet, zemstę, katastrofę, walkę z bakcylem (rozumianym na różne sposoby). Dla futurystycznego „spektaklu postępu” (określenie Tadeusza Peipera) Jasieński pisze scenariusz katastroficzny: buntu, rewolucji, zagłady. Nie jest w tych rozpoznaniach odosobniony, bowiem do pesymistycznych wniosków na temat nowoczesności dochodzą także inni awangardziści, odrzucając optymizm konstruktywizmu.

Miasto nie jest już areną futurystycznej fascynacji, staje się miejscem zupełnie nieprzyjaznym, przestrzenią zagrożenia, kupczenia ideami i ciałem. Nakreślony urbanistyczny obraz Paryża jest zupełnie pejoratywny, urasta do symbolu zła. Miasto nie jest już wielkim nienapisanym poematem (jak u Kurka), z ducha urbanizmu uleciał zachwyt metropolią. Paryż zmienia się w obszar narastającego konfliktu społecznego, który prowadzi najpierw do epidemii, potem do rewolucji; obszar, w którym optymistyczny urbanizm nie jest już możliwy.

„Bezdusznie milczący”, „wielooki” Paryż jest miastem potwornym, wielookim, krzykliwym, okrutnym i przerażającym, pełnym „ołowianostopych ludzi pod ciężkimi skafandrami parasoli”. Obcość miasta, jaka przebija z tych fragmentów, potęguje osamotnienie człowieka. Okrutny Paryż jest też miejscem ostrych podziałów klasowych - wielka przepaść dzieli „zarośniętych, obdartych ludzi”, którzy pozostają bezdomni na pełnych „ryczących automobili” ulicach miasta, i „opasłych galantów” wraz z ich towarzyszkami z wystawnych bankietów, przedstawicieli zamożnej burżuazji i arystokracji; bezdomnych i właścicieli wystawnych domów; głodnych i nasyconych; bezrobotnych robotników i bezdusznych kapitalistów - by wymienić tylko kilka odmalowanych przez poetę kontrastów społecznych.

Zdaje się, że robotnik Pierre, przedstawiciel ciemiężonego i wykorzystywanego proletariatu, to człowiek pochłaniany przez tłum, niezdolny do ocalenia swojej indywidualności, w którym budzi się resentyment: „W głębi bezczynnej świadomości (...) przypominała o sobie poczuciem nieusprawiedliwionej próżni głęboka, czarna, jak szyb nie zasklepiona rana" ${ }^{46}$.

Bohater zbiorowy w postaci burżuazyjnej masy doświadcza kryzysu swojej formacji - pisał o nim, diagnozując zmierzch cywilizacji, Oswald Spengler, wskazując na kosmopolityzm, tanie rozrywki, płytką duchowość, którą Jasieński sugestywnie portretuje:

dostrzegł już tylko migot niezliczonych hotelików, mrowie nalanych krwią, opasłych karków i tysiąc kobiecych profilów, identycznych jak odbitki jednej i tej samej, tak dobrze pamiętanej twarzy. Ze wszystkich bram, przytulone do swych apoplektycznych gachów, wychodziły i wchodziły w gorączkowym pośpiechu dziesiątki i setki Żanet, jedna łudząco podobna do drugiej ${ }^{47}$.

46 B. Jasieński, dz. cyt., s. 46.

47 Tamże, s. 50. 
O ile w Nogach Izoldy Morgan maszyny były głównym zagrożeniem, które inżynier Berg chciał zniszczyć, by nie dopuścić do zagłady świata, o tyle w Pale Paryż to ludzie stają się największym wrogiem, którego robotnik Pierre chce unicestwić. Jednak i w drugiej powieści wytwory techniki ingerują w życie człowieka $^{48}$ : mechanizacja okazuje się niebezpiecznym wytworem cywilizacji. Oba utwory można za Aleksandrem Wójtowiczem określić narracjami o cieniu modernizacji. Lubelski badacz zauważa: „to alegoryczna opowieść o tym, w jaki sposób modernizacja wytwarza swój cień, wywołując postawy katastroficzne, oparte na przekonaniu, że rewersem rozwoju techniki jest dehumanizacja przestrzeni, w jakiej żyje człowiek" ${ }^{49}$. Jasieński tworzy obraz świata-maszyny, który w warstwie dosłownej odsyła nas do futurystycznej obsesji, a w głębszym, metaforycznym znaczeniu - konieczności przebudowy starego porządku, nowej konstrukcji idei, stworzenia zupełnie innej maszynerii społeczno-politycznej:

Świat, jak źle skonstruowana maszyna, więcej niszczy, niż produkuje. Tak dalej niepodobna. Trzeba rozebrać wszystko aż do śrubek, co nieużyteczne - odrzucić, rozebrawszy zmontować na nowo, na fest! Plany leżą gotowe, monterów świerzbią ręce, tylko stare, zardzewiałe żelastwo nie puszcza. Wrosło, pozrastało się w szwach tkanką rdzy - każdy gwint wypadnie odrywać zębami ${ }^{50}$.

Fetysz futurystów przeobraził się w źródło lęków nowoczesnego człowieka, wszechmoc i wszechobecność mechanizacji zrodziły poczucie zagrożenia spowodowane niekontrolowanym rozwojem cywilizacji, w której maszyna jest symbolem „destruktywnego i upokarzającego fizykalizmu nowoczesności” ${ }^{1}$. Rozwój techniki, przemysłu (oznaki nowoczesności) i wzrost znaczenia maszyny powodowały zmiany w psychice ludzi, miały także wpływ na modyfikacje estetyki i tematyki dzieł artystycznych. W innym tekście autor używa bardzo obrazowego porównania, nazywając futurystyczne uwielbienie maszyn „bakcylem nowoczesności”. Inaczej zatem niż Filippo Tommaso Marinetti ${ }^{52}$ czy rosyjscy futuryści (Władimir Majakowski, Dawid Burluk) pojmuje polski pisarz futurystyczne założenia - „przez pojęcie futuryzmu (...) rozumiał (...) pewien

48 K. Lubelski, Anarchia i dyscyplina. O polskich powieściach Brunona Jasieńskiego, „Rocznik Komisji Historycznoliterackiej XI PAN”, Wrocław 1973.

49 A. Wójtowicz, Modernizacja i jej cień. O prozie pierwszej Awangardy [w:] Dwudziestolecie 1918-1939. Odkrycia, fascynacje, zaprzeczenia, red. A.S. Kowalczyk, T. Wójcik, A. Zieniewicz, Warszawa 2010, s. 253.

50 B. Jasieński, dz. cyt., s. 37.

51 B. Olsen, W obronie rzeczy. Archeologia i ontologia przedmiotów, tłum. B. Shallcross, Warszawa 2013, s. 149.

52 Włoscy futuryści głosili afirmację wytworów techniki. A w identyfikacji człowieka z maszyną i w koncepcji człowieka zwielokrotnionego (uomo moltiplicato) widzieli możliwość stworzenia nowego antropologicznego wzorca. 
stan świadomości, który odpowiada procesowi przezwyciężenia maszyny" ${ }^{33}$. Co prawda Jasieński nie odrzucił maszyny jako elementu nowej estetyki, ale odsłonił jej niebezpieczeństwo, ukazał negatywną rolę, wzniecił lęki: „Olbrzymie maszyny, podobne do potwornych dwugłowych smoków, łykały szare kłęby pakuł, brudne jak dym, aby za chwilę wypluć je ciągliwą śliną długich włókien" ${ }^{54}$. Opiewane przez futurystów zdobycze technologii ujawniają swoje złowrogie oblicze, okazują się siłą destrukcyjną, zagrażają nie tylko pojedynczemu ludzkiemu istnieniu, ale także egzystencji całych społeczeństw.

Za symbol katastrofy obrał autor dżumę, ogromnie metaforyczną chorobę, wykorzystywaną w utworach pisarzy, których światopogląd zdawał się bliski Jasieńskiemu i egzystencjalistom (choć nieco później: Dżuma Alberta Camusa opublikowana została 1947 roku), związaną z wizjami, złem, samotnością, wyobcowaniem... Średniowieczna narosła znaczeniami zaraza staje się przyczyną zagłady miasta symbolu, stolicy zachodniej Europy, centrum kapitalistycznego świata. Wykorzystanie obrazu choroby zbliża nas do retoryki katastroficznej w ujęciu (biblijno-)apokaliptycznym - choroba może być bowiem karą za grzechy burżuazyjnego społeczeństwa, za wyzysk i krzywdzące podziały społeczne. Trawiące burżuazyjne społeczeństwo symptomy rozkładu (wyzysk, korupcja, niesprawiedliwość...) zapowiadają nieuchronny koniec w postaci epidemii: „Paryż jak roztwór, do którego ktoś wlał silny odczynnik, rozkładał się w oczach na odrębne składniki”"55.

Wieńczącą kryzys katastrofą okazuje się zaraza, na kartach powieści dokonuje się swoista apokalipsa: „kapitalistyczny Babilon” zostaje ukarany, a sprawiedliwość wymierza jeden z uciśnionych. Jak się okazuje, w trzeciej części powieści jedynymi ocalałymi, wybranymi przez los, których dżuma oszczędziła, są proletariaccy więźniowie, odizolowani od ogniska choroby grubymi więziennymi murami, a wydostają się na ulice miasta niedługo po tym, jak „skonsumowawszy ostatniego paryżanina, dżuma opuściła Paryż równie nagle, jak się w nim zjawiła" ${ }^{56}$. Dżuma niczym narzędzie w rękach sił wyższych oszczędza prawych, każe zaś zgniły kapitalistyczny Zachód, odgrywając w utworze role ideowe, moralne i polityczne (prócz artystycznych oczywiście):

jej ingerencja w naszym odwiecznym sporze była najzupełniej zbyteczna. Absurdalność tej interwencji byłaby w stanie przekonać mnie o istnieniu waszego boga, którego triki, jeśli wierzyć autorom Pisma świętego, nie grzeszyły zbytnią inteligencją. Lata waszej imperialistycznej Europy były już tak czy inaczej policzone i nie było potrzeby przyśpieszać jej końca podobnym wybrykiem ${ }^{57}$.

53 A. Stępień, Bruno Jasieński, Kraków 1974, s. 13.

54 B. Jasieński, dz. cyt., s. 96.

55 Tamże, s. 155.

56 Tamże, s. 161.

57 Tamże, s. 98. 
Bohater wierzy, że nawet bez epidemii konflikty klasowe (które dżuma tylko wyostrzyła) doprowadziłyby do ogólnej rewolucji, zatem choroba spełnia konkretną historiozoficzną rolę, choć raczej jako element irracjonalny: jest przypadkowa. Służy jednak autorowi jako „instrument dogłębnej i wielostronnej (...) analizy imperializmu lat dwudziestych" 58 i współtowarzyszy rewolucji - umożliwia zaprowadzenie nowego porządku w zdziesiątkowanej przez siebie metropolii, a z serca Zachodu - na całym świecie, jak zapowiadają więźniowie w komunikacie: „metropolię świata zmienić na olbrzymie miasto komunistyczne, ognisko i komórkę, z której ustrój nasz rozpromieniuje na cały kontynent"59.

Gestem rewolucyjnym jest „podpalenie” Paryża - symbolu kulturowego mitu Zachodu, zepsucia burżuazyjnej zbiorowości, która, według narratora, nie wytworzyła żadnych wartościowych modeli społecznego współbycia ani użytecznych dla ogółu wartości, a której sztandarowe idee kończą, jak w poniższym fragmencie: „Na frontonie więzienia girlandą spełzłych liter kokietował przechodniów poczerniały napis: „Wolność - Równość - Braterstwo", jak wypłowiała żałobna wstęga na zapuszczonej mogile Wielkiej Rewolucji Francuskiej”"60. Metropolia pozbawiona wyższych wartości budzi odrazę, opisywana jest z wykorzystaniem metafory domów publicznych, dancingów, prostytucji. Paryż nie zostaje podpalony dosłownie, autor dokonuje innego anarchistycznego aktu: zdehumanizowana zachodnia cywilizacja zostaje zniszczona za pomocą ognia symbolicznego - bakcyla dżumy, który wypala miejsce na nowe wartości i idee.

Jasieński zrealizował w ten przewrotny sposób postulat Marinettiego, który w Akcie zatożycielskim i maniféscie futuryzmu nawoływał do wyrazistego przeciwstawiania się kulturze przeszłości i jej symbolom. A stolica Francji takim symbolem również była, mało tego, była miejscem symbolicznym dla kwestionowanego przez Jasieńskiego nurtu futurystycznego - to tam bowiem ogłaszał włoski przywódca ruchu swoje hasła, tam tworzyli futuryści różnych narodowości, to miasto uznano za centrum artystycznego świata i starego porządku:

W powieści Jasieńskiego zbiegły się dwie tendencje destrukcyjne: autodestrukcja futurystyczna oraz - implikowana polityczną ideą - zagłada symbolu świata kapitalistycznego. Młodzieńcze doświadczenie strategii skandalu przerodziło się w świadomą postawę artystycznego i ideologicznego buntu ${ }^{61}$.

Pierre, romantyczny samotny rewolucjonista, który raczej jest destruktorem niż prawodawcą nowego porządku, ucieka się do jedynej możliwości, jaka pozostaje: do radykalnego gestu.

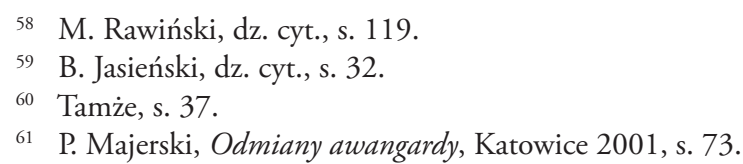


Dwa omówione powyżej modernistyczne utwory odczytać możemy jako wyraz uczuć katastroficznych, teksty prezentujące nie tylko czy też nie tyle poglądy pesymistyczne, co kreślące wizje totalnego zagrożenia ukrytego pod postacią zarazy. Irzykowski i Jasieński - mimo oczywistych różnic - dokonują krytyki cywilizacji i społeczeństwa oraz prorokują zagładę tychże, odwołując się do symboliki chorobowej i apokaliptycznej. Upadek i krytyka cywilizacji u autora Zarazy $w$ Bergamo przybierają nieco inny ton niż wizja społeczno-politycznych konsekwencji i zagrożeń rewolucji u Jasieńskiego. Katastrofizm Irzykowskiego pozostaje ciemny, choć w groteskowym wydaniu, zaś Jasieński do stworzenia własnego katastroficznego modelu prozy wykorzystuje utopię, sensacyjność powieści popularnej. Podczas gdy u pierwszego spełniająca się w zarazie apokalipsa oznacza zgubę wartości, odejście wszelkich ideałów, śmiertelne zagrożenie dla cywilizacji i kres dotychczasowego porządku, u drugiego pisarza rewolucja nadbudowana na chaosie epidemii dawać ma nadzieję na lepsze jutro i nowy porządek. Historie epidemii pokazują, że zaraza toruje drogę do wymazania starego porządku i gwarantuje zaprowadzenie innego, nowego ładu - swoistego świata po katastrofie. Zaraza nie jest zatem postrzegana przez pisarzy tylko jako kara za grzechy, retrybucja moralna czy widmo śmierci.

Cywilizacje od wieków toczyły walki z różnymi powracającymi chorobami, a epidemie miały ogromny wpływ na funkcjonowanie jednostek i społeczeństw w świecie. Występowanie zgonów spowodowanych epidemiami, kryzysy ekonomiczne, ogólnie panujący nastrój lęku to tylko niektóre z elementów wywołujących daleko idące zmiany społeczne, które znalazły odbicie w literaturze. Każda cywilizacja miała do czynienia z epidemiami, zatem każda wytworzyła swoiste interpretacje tego zjawiska, obudowała je systemem znaków i znaczeń, tworząc przynależną im mitologię. Dawało to bezpieczne obramowanie zjawiska, które wymykało się empirii i racjonalności, które bez tego byłoby pozbawionym sensu chaosem.

\section{Bibliografia}

Aberth J., Spektakle masowej śmierci. Plagi, zarazy, epidemie, tłum. L. Karnas, Warszawa 2012.

Balcerzan E., Styl i poetyka twórczości dwujęzycznej Brunona Jasieńskiego, WrocławWarszawa-Kraków 1968.

Bujnicki T., Bruno Jasieński [w:] Literatura polska w okresie międzywojennym, red. I. Maciejewska, J. Trznadel, M. Pokrasenowa, t. 3: Obraz literatury polskiej XIX i XX wieku, Kraków 1993.

Bujnicki T., Twórczość prozatorska Brunona Jasieńskiego [w:] tegoż, Bunt żywiotów i logika dziejów. W kregu idei polskiej lewicy, Katowice 1984.

Cartwright F.F., Biddiss M., Niewidoczny wróg. Zarazy i historia, tłum. M. Wyrwas-Wiśniewska, Warszawa 2005. 
Dziarnowska J., Stowo o Brunonie Jasieńskim, Warszawa 1978.

Girard R.R., Koziot ofiarny, tłum. M. Goszczyńska, Łódź 1987.

Irzykowski K., Zaraza w Bergamo [w:] tegoż, Wiersze i dramaty, red. A. Lam, Kraków 1977.

Jaworski K., Bruno Jasieński w Paryżu (1925-1929), Kielce 2003.

Jaworski K., Przestrzeń fabularna i uksztattowanie języka narracji a idea polityczna. Na przyktadzie powieści Brunona Jasieńskiego „Pale Paryż”, „Studia Filologiczne Akademii Świętokrzyskiej” 2002, t. 17.

Kitrasiewicz P., Morand-Jasieński. Pojedynek na miasta [w:] B. Jasieński, Palę Paryż, Warszawa 2005.

Kłosińska K., Katastroficzna odmiana powieści popularnej [w:] Katastrofizm i awangarda, red. T. Bujnicki, T. Kłak, Katowice 1979.

Kolesnikoff N.N., Bruno Jasieński: His Evolution from Futurism to Socialist Realism, Waterloo, Ont. 1982.

Lubelski K., Anarchia i dyscyplina. O polskich powieściach Brunona Jasieńskiego, „Rocznik Komisji Historycznoliterackiej XI PAN”, Wrocław 1973.

Łobodowski J., Literatura proletariacka, „Kurier Lubelski”, 26.03.1932, nr 86.

Majerski P., Odmiany awangardy, Katowice 2001.

Mitzner P., Śmierć futurysty, „Karta” 1993, nr 11.

Morand P., Palę Moskwe [w:] tegoż, Swawolna Europa, Warszawa 1928.

Olsen B., W obronie rzeczy. Archeologia i ontologia przedmiotów, tłum. B. Shallcross, Warszawa 2013.

Rawiński M., Wobec mitu zagrożenia Zachodu (O „Palę Paryż” Brunona Jasieńskiego) [w:] O prozie polskiej XX wieku, red. A. Hutnikiewicz, H. Zaworska, Wroclaw 1971.

Ruffié J., Sournia J.Ch., Historia epidemii. Od dżumy do AIDS, tłum. B.A. Matusiak, Warszawa 1996.

Speina J., Powieści Stanisawa Ignacego Witkiewicza, Toruń 1965.

Stępień M., Bruno Jasieński, Kraków 1974.

Sznajderman M., Zaraza. Mitologia dżumy, cholery i AIDS, Warszawa 1994.

Szymański J. [A. Stawar], „Palę Paryż”, „Miesięcznik Literacki” 1929, nr 1.

Waligóra J., Mtodopolska discors concordia. „Zaraza w Bergamo” Karola Irzykowskiego [w:] Człowiek wobec epidemii chorób zakaźnych od starożytności po czasy wspótczesne w świecie literatury i medycyny, red. E. Łoch, G. Wallner, E. Fllis-Czerniak, t. 9, Lublin 2011.

Wiedemann A., Konceptualizm literacki Karola Irzykowskiego: dziennik, wiersze, dramaty, „Pamiętnik Literacki” 1995, nr 4.

Wójtowicz A., Modernizacja i jej cień. O prozie pierwszej Awangardy [w:] Dwudziestolecie 1918-1939. Odkrycia, fascynacje, zaprzeczenia, red. A.S. Kowalczyk, T. Wójcik, A. Zieniewicz, Warszawa 2010.

Wyka K., Wspomnienie o katastrofizmie [w:] tegoż, Rzecz wyobraźni, Warszawa 1977. 